\title{
A Mild and Selective Protecting and Reversed Modification of Thiols
}

\author{
Xiangmin $\mathrm{Li}^{\mathrm{a}}$, Hongxian $\mathrm{Li}^{\mathrm{a}}$, Wei Yang ${ }^{\mathrm{b}}$, Jinchen Zhuang ${ }^{\mathrm{a}}$, Hao $\mathrm{Li}^{\mathrm{a}}{ }^{\mathrm{a}}$, and Wei Wang ${ }^{\mathrm{a}, \mathrm{c}}$, \\ ${ }^{a}$ State Key Laboratory of Bioengineering Reactor, Shanghai Key Laboratory of New Drug Design, and School of Pharmacy, East China University of Science \\ and Technology, 130 Mei-long Road, Shanghai 200237, China \\ ${ }^{b}$ Shanghai Institute of Materia Medica, Chinese Academy of Sciences, 555 Zuchongzhi Road, Shanghai 201203, China \\ ${ }^{c}$ Department of Chemistry and Chemical Biology, University of New Mexico, Albuquerque, NM 87131-0001, USA
}

\section{ARTICLE INFO}

\section{Article history:}

Received

Received in revised form

Accepted

Available online

\section{Keywords:}

Thiols

Bromomaleimide

Protecting

Deprotecting

Selective

\section{ABSTRACT}

One selective thiol-protecting study has been investigated for a wide range of thiols including general thiols and thiols containing multiple functional groups. The reactions of bromomaleimides and thiols under the mild condition afforded the protected products in excellent yields. The thiols can be recovered very quickly by using dithiothreitol (DTT) under the mild condition.

* Corresponding author. Tel./fax: +86 (21) 64253299 (H.L.); tel.: +1 (505) 277 0756; fax: +1 (505) 2772609 (W.W.).

E-mail addresses: hli77@ecust.edu.cn (H. Li),wwang@unm.edu (W. Wang).

C 2016. This manuscript version is made available under the Elsevier user license http://www.elsevier.com/open-access/userlicense/1.0/ 
Thiols are the most important nucleophilic residues for studying peptides and proteins in chemical biology. ${ }^{1}$ Synthesis of thiol-containing biomolecules is an important, yet challenging work which usually was puzzled by the formation of disulfide bond and unexpected acetylation or alkylation. ${ }^{2,3}$ In the past few decades, selective chemical modification, fluorescent labeling and detection of thiols in proteins is widely used in a range of fundamental biological and biophysical studies. ${ }^{4}$ Significant research efforts has been realized that the optical probes for various biological thiols to achieve high sensitivity, low cost, and ease of detection have been developed. ${ }^{4}$ Meanwhile, identification of reagents that enable blocking or labeling of protein thiols with high selectivity and conversion yields has attracted great attention. ${ }^{5}$ Common thiol-protecting groups such as thioethers (trityl, benzyls and $t$-butyl), ${ }^{6}$ thioesters ${ }^{7}$ and disulfides $^{8}$ have limited scope of applications due to either unsatisfactory stability profiles or the harsh deprotecting conditions. The acetamidomethyl (Acm) protecting group developed by Hirschmann and co-workers has been shown to be useful in the synthesis of peptides. ${ }^{9}$ Unfortunately, the reagents could be dimmed by the use of toxic heavy metals in deprotection process. For the purpose of protecting Cys side chain in peptides and proteins, Liu and co-workers developed a thiol protecting group called Hqm group. ${ }^{10}$ It's a good-quality protecting group, however, several synthetic steps were required for synthesis and protecting processes. In order to protect the thiols in peptide condensation reactions, phenacyl and $N$-methylphenacyloxycarbamidomethyl were developed to improve thioether-based thiol-protecting groups by Hojo and co-workers.

${ }^{11}$ Nevertheless, the carbonyl of these protecting groups may react with amino residues of peptides, which need to be protected before the thiol-protecting process. Other protecting groups such as $p$-toluenesulfonylacetylene ${ }^{12}$ and quinolone ${ }^{13}$ have limited utilization due to the instability in the presence of amino or the high protecting temperature.

Maleimides have been proved to be one of the most widely used reactive motifs for cysteine modification. ${ }^{1}$ Bromomaleimides, developed by Baker and co-workers, react rapidly with protected cysteine to afford thiomaleimides. ${ }^{14}$ Recently, bromomaleimides have been successfully applied in the synthesis of polymers, ${ }^{15}$ protein labelling, ${ }^{16}$ and peptide platforms ${ }^{17}$ with protected cysteines. All cysteines used in these methods were protected cysteines. To the best of our knowledge, the efficient protecting and reversed modification of general thiols or thiols with active functional groups has not been studied. Herein, we wish to focus on bromomaleimides as selective thiol-protecting reagents to a wide range of thiols. Furthermore, DTT has been applied to an efficient deprotecting reagent of protected thiols under the mild condition.

The protecting group bromo- $N$-R-maleimide $\mathbf{1}$ could be easily synthesized from the corresponding $N$-R-maleimides in two steps. ${ }^{18}$ In the initial experiment, bromo- $N$-methylmaleimide 1a and commercially available $\mathrm{N}$-Boc-Cys-OMe $\mathbf{2 a}$ were tested in the model reaction (Table 1$)$. Treatment of $2 \mathbf{a}(0.263 \mathrm{mmol})$ and 1a $(0.263 \mathrm{mmol})$ with 3 equiv of $\mathrm{Et}_{3} \mathrm{~N}$ in THF $(5 \mathrm{~mL})$ resulted in a rapid and complete reaction in 20 min with excellent yield (99\%, Table 1, entry 1). Different solvents and bases were tested for the reactions. The reactions in other solvents, such as $\mathrm{MeOH}$, toluene, $\mathrm{CH}_{2} \mathrm{Cl}_{2}$ and water, also gave the products in excellent yields $(>93 \%$ ) within 20 min (Table 1 , entries $2-4$ ). To our delight, it was convinced that the protecting process was easy to implement at room temperature, which even took place in water as solvent and DMF as base (Table 1, entry 5). Other organic or inorganic bases, such as DMAP, DIPEA and $\mathrm{NaHCO}_{3}$ were also suitable for this reaction. On the basis of these exploratory studies, we probed various bromomaleimides derived thiolprotecting groups with $\mathrm{N}$-Boc-Cys-OMe under the treatment of $\mathrm{Et}_{3} \mathrm{~N}$ in THF. It was found that the reactions with small protecting groups, such as $\mathrm{H}, \mathrm{Me}$ and $\mathrm{Et}$, took place very quickly to give the products in high yields (Table 1 , entries $1,6-7)$. In contrast, the bromomaleimide with bigger substitutes, such as bromo- $N$-phenylmaleimide $\mathbf{1 d}$ and bromo- $N$-benzylmaleimide 1e, afforded the corresponding products in lower yields (Table 1, entries 8-9). Longer reaction time could not raise the reaction yields. We envisioned that both steric and electronic effects of substituents accounts for the yield differences. Based on the above results, the optimized reaction condition was found: THF as solvent, $\mathrm{Et}_{3} \mathrm{~N}$ as base, bromo- $N$-methylmaleimide $\mathbf{1 a}$ or bromomaleimide $\mathbf{1 b}$ as the protecting reactants.

Table 1. Optimization of reaction conditions ${ }^{a}$

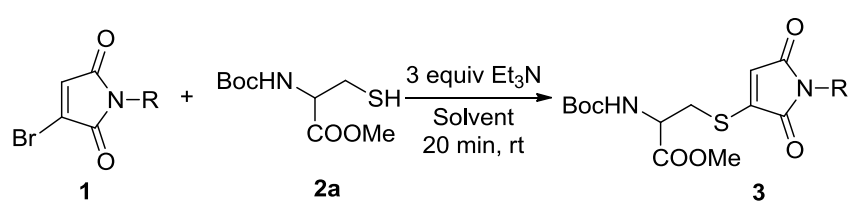

\begin{tabular}{llll}
\hline entry & $\mathrm{R}$ & solvent & yield $(\%)^{b}$ \\
\hline 1 & $\mathrm{Me}$ & $\mathrm{THF}$ & 99 \\
2 & $\mathrm{Me}$ & $\mathrm{MeOH}$ & 96 \\
3 & $\mathrm{Me}$ & toluene & 93 \\
4 & $\mathrm{Me}$ & $\mathrm{CH}_{2} \mathrm{Cl}_{2}$ & 95 \\
$5^{c}$ & $\mathrm{Me}$ & $\mathrm{H} 2 \mathrm{O}$ & 91 \\
6 & $\mathrm{H}$ & $\mathrm{THF}$ & 97 \\
7 & $\mathrm{Et}$ & $\mathrm{THF}$ & 92 \\
8 & $\mathrm{Ph}$ & $\mathrm{THF}$ & 83 \\
9 & $\mathrm{Bn}$ & $\mathrm{THF}$ & 77 \\
\hline
\end{tabular}

${ }^{a}$ Reaction condition: To a solution of $\mathbf{2 a}(61.8 \mathrm{mg}, 0.263 \mathrm{mmol})$ in solvents $(5 \mathrm{~mL})$ was added $\mathrm{Et}_{3} \mathrm{~N}(0.789 \mathrm{mmol})$ and $\mathbf{1}(0.263 \mathrm{mmol})$ and the resulting mixture was stirred for $20 \mathrm{~min}$ at $\mathrm{rt}$.

${ }^{b}$ Isolated yields.

${ }^{c} 0.5 \mathrm{~mL} \mathrm{DMF}$ as base and $4.5 \mathrm{~mL} \mathrm{H}_{2} \mathrm{O}$ was used.

With the optimal reaction condition in hand, we turned our attention to probing the scope of different thiols (Table 2). Satisfactorily, almost all reactions finished within half an hour to give the protected products in excellent yields (Table 2). Linear thiols reacted smoothly and finished in $20 \mathrm{~min}$ to afford the products in excellent yields (3b-3d). Branched isobutylthiol had similar reactivity as linear thiols (3e). Steric effect had great effect on this reaction. Bulky cyclohexanethiol gave high yield while longer reaction time was needed (3f). More bulky $t$ butylthiol needed $6 \mathrm{~h}$ to finish the reaction (3g). Interestingly, triphenylmethylthiol reacted much faster than $t$-butylthiol under the same reaction condition even though whose steric effect was greater than $t$-butylthiol $(\mathbf{3 h}, 30 \mathrm{~min})$. The heterocyclicthiols, such as thiophene-2-thiol and 1-methyl- $1 H$-imidazole-2-thiol, afforded the corresponding products with high yields (3i-3j).

Having tested the reactivity of general thiols with bromomaleimides, next we questioned whether thiols containing functional groups also had good selectivities. Various thiols with different functional groups were investigated in the thiol protecting reactions (Table 3 ). Thiol substrates containing hydroxyl, phenolic hydroxyl and phenylamino groups gave the only thiol protected products in excellent yields without any other byproduct (3k-3m). Heterocyclic 5-amino-1,3,4thiadiazole-2-thiol afforded the mono thiol addition product $3 \mathbf{n}$ in high yield. Both thiol and carboxyl are common groups in drug molecules. In order to investigate the effects of carboxyl on the thiol-protecting reactions, we selected tiopronin 20 and captopril 
Table 2. Thiol-protecting reactions for general thiols ${ }^{a}$

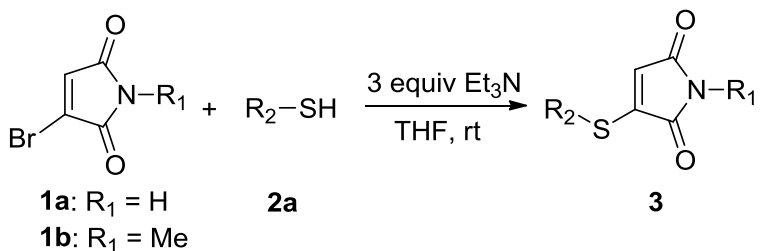

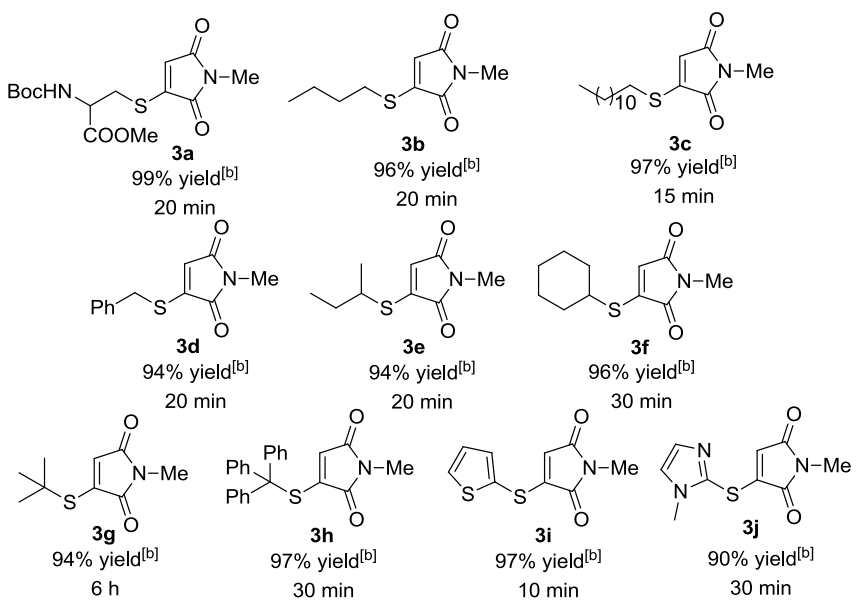

${ }^{a}$ Reaction condition: To a solution of $\mathbf{2}(0.263 \mathrm{mmol})$ in THF $(5 \mathrm{~mL})$ was added $\mathrm{Et}_{3} \mathrm{~N}(0.789 \mathrm{mmol})$ and $\mathbf{1}(0.263 \mathrm{mmol})$ and the mixture was stirred for the indicated time at $\mathrm{rt}$.

${ }^{b}$ Isolated yields.

$\mathbf{2 p}$ as models for the research. The reactions proceeded very quickly to give single thiol protected products in excellent yields (3o-3p). Encouraged by the promising results, we moved on to investigate the protecting method for water-soluble substrates, such as cysteine and glutathione. Water-soluble substrates containing mercapto, carboxy and amino could not easy to be

Table 3. Thiol-protecting reactions for thiols with functional groups $^{a}$

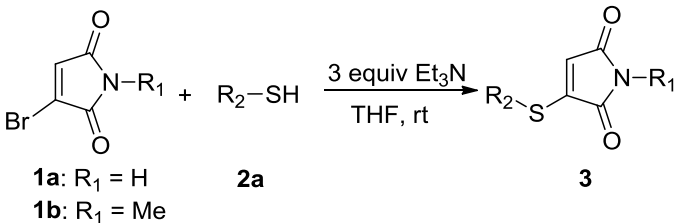

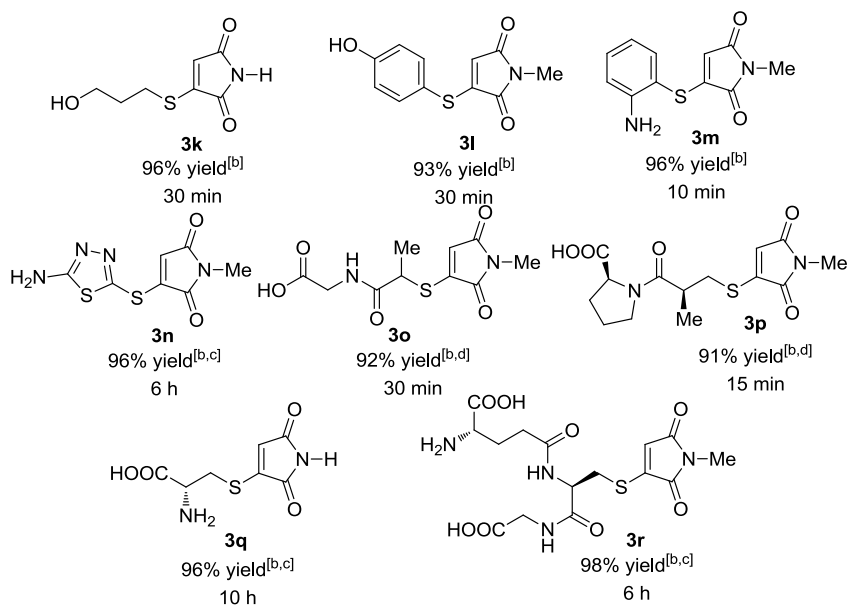

${ }^{a}$ Reaction condition: To a solution of $\mathbf{2}(0.263 \mathrm{mmol})$ in THF $(5 \mathrm{~mL})$ was added $\mathrm{Et}_{3} \mathrm{~N}(0.789 \mathrm{mmol})$ and $\mathbf{1}(0.263 \mathrm{mmol})$ and the mixture was stirred for the indicated time at rt.

${ }^{b}$ Isolated yields.

${ }^{c} \mathrm{H}_{2} \mathrm{O}$ was used as solvent without the addition of $\mathrm{Et}_{3} \mathrm{~N}$.

${ }^{d} \mathrm{NaHSO}_{4}(2.63 \mathrm{mmol})$ and anhydrous $\mathrm{MgSO}_{4}(1 \mathrm{~g})$ was added into the mixture. protected by conventional methods as a result of low solubility in organic solvents. Inspired by the result of good reaction in water in the optimization process, we mixed bromomaleimides and water-soluble thiol substrates in water under vigorous stirring. These substrates contain free amine group which can be used as base instead of $\mathrm{Et}_{3} \mathrm{~N}$ in the reaction. When the reaction completed, water was removed under vacuum and the excess protecting reagent was washed by $\mathrm{CH}_{2} \mathrm{Cl}_{2}$. To our delight, the desired thiol protected products were obtained in excellent yields although much longer reaction time was needed (3q-3r).

Scheme 1. Thiol-protecting with amino-protecting reactions.

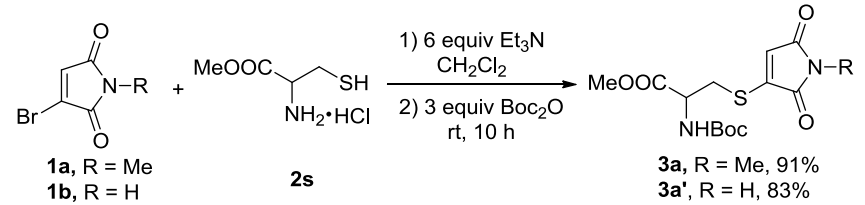

Next, we wanted to investigate two protecting reactions to protect thiol and amine by using a "one-pot" process. In our exploratory study, the commercially available methyl 2-amino-3mercaptopropanoate hydrochloride $\mathbf{2 s}$ was chosen as a model substrate for the proposed one-pot protecting reactions (Scheme 1). After the addition of $\mathrm{Et}_{3} \mathrm{~N}$ into the mixture of substrates in $\mathrm{CH}_{2} \mathrm{Cl}_{2}$ for $20 \mathrm{~min}, \mathrm{Boc}_{2} \mathrm{O}$ was added and stirred for another $10 \mathrm{~h}$

Table 4. Deprotection of maleimide protected thiols ${ }^{a}$

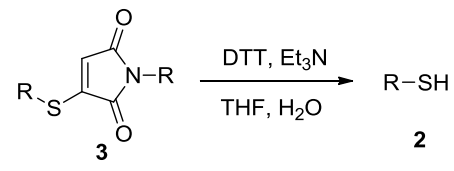

\begin{tabular}{llllll}
\hline $\begin{array}{l}\text { entr } \\
\mathrm{y}\end{array}$ & $\mathbf{3}$ & $\begin{array}{l}\text { DTT } \\
\text { (equiv) }\end{array}$ & $\begin{array}{l}\text { TEA } \\
\text { (equiv) }\end{array}$ & $\mathrm{t}(\mathrm{min})$ & $\begin{array}{l}\text { yie } \\
(\%)\end{array}$ \\
\hline
\end{tabular}

1<smiles>COC(=O)C(CSC1=CC(=O)N(N)C1=O)NC(=O)OCc1ccccc1</smiles>

2<smiles>COC(=O)C(CSC1=CC(=O)NC1=O)NC(=O)OCc1ccccc1</smiles>

3<smiles>[M]C1C(=O)N([M])C(=O)C=C1Sc1ccc(O)cc1</smiles>
3.0

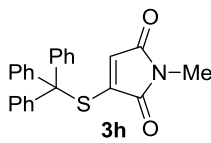

5

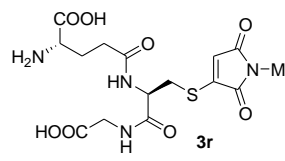

3.0

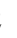


at $\mathrm{rt}$ to give the desired product. Both bromomaleimide and bromo-N-methylmaleimide can be used as thiol protecting groups to afford products $3 \mathrm{a}$ and $3 \mathrm{a}$ ' in high yields.

In our effort on the construction and expanding scope of the synthetically useful thiol protecting method, we also wish to develop an efficient deprotecting method. In Baker and coworkers' work, expensive TCEP in buffer was applied to reverse the modification of cysteine and protein. ${ }^{14}$ Later on, cheaper 2 mercaptoethanol (BME) and 1,2-ethanedithiol (EDT) have been applied to the cleavage strategy. However, large scale of BME (100 equivalents) and longer reaction time of EDT (24 h) was needed. ${ }^{16}$ We tested a series of potential deprotection reagents such as triphenylphosphine, tributylphosphine and DTT. The results showed that DTT in THF and water, under the treatment of $\mathrm{Et}_{3} \mathrm{~N}$, was very efficient for cleaving C-S bond. Several selective substrates were chosen for the deprotection study and the results were listed in table 4 . In the deprotecting reaction of 3a, the loading of DTT can be as low as 1.1 equiv and only 0.1 equiv of $\mathrm{Et}_{3} \mathrm{~N}$ was needed. For other substrates, no more than 3 equiv of DTT and $\mathrm{Et}_{3} \mathrm{~N}$ was used to give the corresponding deprotected thiols in high to excellent yields. It should be noted that all reactions completed within $30 \mathrm{~min}$. With the demonstrated results, we have illustrated DTT as a synthetically useful deprotecting reagent for thiol protecting method.

In summary, bromomaleimides have been used as an efficient and selective thiol-protecting group, which is applicable for a wide range of thiols including general thiols and thiols containing multiple functional groups. The reaction was proceeded very fast under the mild condition to give protected thiols in excellent yields. Furthermore, the protected group can be easily removed under the mild condition by using low equivalent of DTT to release the sulfhydryl moiety.

\section{Acknowledgments}

Financial support of this research from the program for Professor of Special Appointment (Eastern Scholar) at Shanghai Institutions of Higher Learning (No. 201226, H. L.), the National Science Foundation of China (21372073, 21572054 and 21572055), the Fundamental Research Funds for the Central Universities and East China University of Science and Technology, and the China 111 Project (Grant B07023) is gratefully acknowledged.

\section{References and notes}

1. (a) Merrifield, R. B. J. Am. Chem. Soc. 1963, 85, 2149. (b) Dawson, P. E.; Muir, T. W.; Clark-Lewis, I.; Kent, S. B. H. Science 1994, 266, 776. (c) Chalker, J. M.; Bernardes, G. J. L.; Lin, Y. A.; Davis, B. G. Chem. Asian J., 2009, 4, 630.

2. (a) Dawson, P. E.; Kent, S. B. H. Annu. Rev. Biochem., 2000, 69, 923. (b) Kent, S. B. H. Chem. Soc. Rev., 2009, 38, 338.

3. Isidro-Llobet, A.; Alvarez, M.; Albericio, F. Chem. Rev., 2009,109, 2455.

4. (a) Chen, X.; Zhou, Y.; Peng, X.; Yoon, J. Chem. Soc. Rev., 2010, 39, 2120. (b) Jung, H. S.; Chen, X.; Kim, J. S.; Yoon, J. Chem. Soc. Rev., 2013, 42, 6019 .

5. (a) Zhang, D.; Devarie-Baez, N. O.; Li, Q.; Lancaster Jr, J. R.; Xian, M. Org. Lett., 2012, 14, 3396. (b) Toda, N.; Asano, S.; Barbas III, C. F. Angew. Chem. 2013, 125, 12824; Angew. Chem. Int. Ed., 2013, 52, 12592.

6. (a) Stuhr-Hansen, N. Synth. Commun., 2003, 33, 641. (b) Maltese, M. J. Org. Chem., 2001, 66, 7615. (c) Denis, B.; Trifiliefe, E. J. Peptide Sci., 2000, 6, 372.

7. (a) Neindre, M. L.; Magny, B.; Nicolay, R. Polym. Chem., 2013, 4, 5577. (b) Zheng, J.; Tang, S.; Huang, Y.; Liu, L. Acc. Chem. Res., 2013, 46, 2475.

8. Field, L.; Ravichandran, R. J. Org. Chem., 1979, 44, 2624.

9. (a) Veber, D.; Milkowski, J.; Varga, S.; Denkewalter, R.; Hirschmann, R. J. Am. Chem. Soc., 1972, 94, 5456. (b) Pentelute B. L.; Kent, S. B. H. Org. Lett., 2007, 9, 687. (c) Kan, C.; Trzupek, J. D.; Wu, B.; Wan, Q.; Chen, G.; Tan, Z.; Yuan, Y.; Danishefsky, S. J. J. Am. Chem. Soc., 2009, 131 , 5438
10. Shen, F.; Zhang, Z. P.; Li, J. B.; Lin, Y.; Liu, L. Org. Lett., 2011, 13, 568

11. (a) Katayama, H.; Hojo, H. Org. Biomol. Chem., 2013, 11, 4405. (b) Katayama, H.; Nakahara, Y.; Hojo, H. Org. Biomol. Chem. 2011, 9, 4653

12. Arjona, O.; Iradier, F.; Medel, R.; Plumet, J. J. Org. Chem., 1999 64, 6090 .

13. Zhang, J.; Matteucci, M. D. Tetrahedron Lett., 1999, 40, 1467.

14. (a) Tedaldi, L. M.; Smith, M. E. B.; Nathani, R. I.; Baker, J. R. Chem. Commun., 2009, 43, 6583. (b) Smith, M. E. B.; Schumacher, F. F.; Ryan, C. P.; Tedaldi, L. M.; Papaioannou, D. Waksman, G.; Caddick, S.; Baker, J. R. J. Am. Chem. Soc., 2010, 132, 1960. (c) Youziel, J.; Akhbar, A. R.; Aziz, Q.; Smith, M. E. B.; Caddick, S.; Tinker, A.; Baker, J. R. Org. Biomol. Chem., 2014, 12, 557. (d) Marculescu, C.; Kossen, H.; Morgan, R. E.; Mayer, P.; Fletcher, S. A.; Tolner, B.; Chester, K. A.; Jones, L. H.; Baker, J. R. Chem. Commun., 2014, 50, 7139.

15. Yan, J.-J.; Wang, D.; Wu, D.-C.; You, Y.-Z. Chem. Commun., 2013, 49, 6057.

16. Nathani, R. I.; Chudasama, V.; Ryan, C. P.; Moody, P. R.; Morgan, R. E.; Fitzmaurice, R. J.; Smith, M. E. B.; Baker, J. R.; Caddick, S. Org. Biomol. Chem., 2013, 11, 2408.

17. Ramesh, S.; Cherkupally, P.; Govender, T.; Kruger, H. G.; Albericio, F.; de la Torre, B. G. Org. Lett., 2015, 17, 464.

18. Davis, S. J.; Rondestvedt, C. S. Chem. Ind., 1956, 845.

\section{Supplementary Material}

All experimental procedures, spectroscopic data associated with this article can be found, in the online version. 


\section{Graphic Abstract}<smiles>N[C@@H](CCC(=O)N[C@@H](C[Si])C(=O)NCC(=O)O)C(=O)O</smiles><smiles>CN1C(=O)C=C(Br)C1=O</smiles><smiles>CN1C(=O)C=C(SC[C@H](NC(=O)CC[C@H](N)C(=O)O)C(=O)NCC(=O)O)C1=O</smiles> 